\title{
Corporate Control Over Seeds: Limiting Access and Farmers' Rights
}

\section{Patrick Mulvany}

Most food in the world is grown, collected and harvested by more than a billion small-scale farmers, pastoralists and artisanal fisherfolk. This food is mainly sold, processed, resold and consumed locally, thereby providing the foundation of peoples' nutrition, incomes and economies across the world. In subSaharan Africa, for example, women produce 70 per cent of the food, mainly for local consumption (Commission for Africa 2005). At a time when halving world poverty and eradicating hunger, in a world plagued simultaneously and perversely by hunger and obesity, are at the forefront of the international development agenda, reinforcing the diversity and vibrancy of local food systems should also be at the forefront of the international policy agenda.

Yet, the rules that govern food and agriculture at all levels - local, national and international - are designed a priori to facilitate not local, but international trade. This reduces diversity and concentrates the wealth of the world's food economies in the hands of ever fewer multinational corporations, while the majority of the world's smallscale food producers, processors, local traders and consumers including, crucially, the poor and malnourished, are marginalised.

The diversity upon which local food systems depend is the product of human interaction with nature - specifically through the development of agricultural biodiversity and the wide range of genetic resources for food and agriculture, facilitated by their open exchange between peoples, communities, countries and continents. These resources and their free availability is under threat from, among other things, their privatisation, as required by the World Trade Organization's (WTO) Agreement on Trade-Related Aspects of Intellectual
Property Rights (TRIPs), specifically Article 27.3(b). This has led to increased concentration of ownership of genetic resources for food and agriculture with only ten corporations controlling more than 30 per cent of global seed sales and only seven controlling more than 85 per cent of maize germplasm. Such concentration mirrors that which occurs beyond the "farm gate" in the food marketing and retailing industry where four of five corporations control the supply of any particular commodity or food (UKFG 2003).

The much-disputed TRIPs Article 27.3(b) requires all members of the WTO to provide plant variety protection through patents or sui generis forms of monopoly rights. It imposes a system that weakens informal sector knowledge systems and thereby facilitates the concentration of knowledge and power.

This trend of commodification, privatisation and concentration of knowledge is prevalent, through moving genetic resources and its associated knowledge from the informal sector into the formal sector, and from public domain to private ownership. It results in the loss of control by, and benefits for, the originators of that knowledge and its associated biological resources, especially people and communities in the informal sector that developed agricultural biodiversity.

How this concentration of resources has occurred requires some understanding of knowledge systems and the way in which power over knowledge has been conferred on privileged sections of society.

Globally, there are two distinct and conflictive knowledge systems: those of the formal sector (both private and public institutions), and those of the informal sector, of communities and individuals.

IDS Bulletin Vol 36 No 2 June 2005 ㄷ Institute of Development Studies 


\section{Agricultural Biodiversity}

Agricultural biodiversity encompasses the variety and variability of animals, plants and micro-organisms which are necessary to sustain key functions of the agroecosystem, its structure and processes for, and in support of, food production and food security. It results from the interaction between the environment, genetic resources and the management systems and practices used by culturally diverse peoples resulting in the different ways land and water resources are used for production. It is simultaneously the product of and the basis for diverse, sustainable food production systems.

Agricultural biodiversity has spatial, temporal and scale dimensions, especially at agroecosystem levels. These agro-ecosystems - ecosystems that are used for agriculture - are determined by three sets of factors: the genetic resources, the physical environment and the human management practices. There are virtually no ecosystems in the world that are "natural" in the sense of having escaped human influence. Most ecosystems have been to some extent modified or cultivated by human activity for the production of food and income and for livelihood security.

Agricultural biodiversity thus comprises the variety and variability of animals, plants and micro-organisms used directly or indirectly for food and agriculture (including, in the Food and Agriculture Organization (FAO) definition, crops, livestock, forestry and fisheries). It comprises the diversity of genetic resources (varieties, breeds, etc.) and species used for food, fodder, fibre, fuel and pharmaceuticals. It also includes the diversity of non-harvested species that support production (e.g. soil micro-organisms, predators, pollinators and so on) and those in the wider environment that support agro-ecosystems (agricultural, pastoral, forest and aquatic), as well as the diversity of the agro-ecosystems themselves (FAO 1999). ${ }^{1}$

The formal sector knowledge systems are codified, are recorded in writing and are defended through national and international law; the knowledge systems of the informal sector are often oral, are built on trust and are defended through the norms and practices of traditional institutions. The intellectual property of the former is recognised in law in industrialised countries and in the industrial sectors of developing countries and implemented through application of WTO rules.

The latter has weak jurisprudence in its defence: there are no mechanisms to implement legislation and, in most countries, none has yet been enacted, despite ratification of a number of international agreements, such as the Convention on Biological Diversity (CBD), which includes measures for the protection of indigenous knowledge, the conservation of genetic resources and the equitable sharing of benefits from their sustainable use (Mulvany 1999).

The African Union has adopted a Model Law on Community Rights (Egziabher 2002) that addresses these issues in an African context. It applies to biological resources both in situ and ex situ as well as their derivatives and to community knowledge and technologies. But it is not designed to apply restrictions on the traditional way of access, use or exchange of biological resources as well as knowledge and technologies by and between local communities and the sharing of benefits based upon their customary practices.

The formalisation of these knowledge systems started in the UK with the adoption of the Seeds Act in 1920. This Act was designed benignly to protect an increasing number of growers, especially demobilised soldiers with allotments for growing vegetables, from rogue seed traders. The legislation enacted quality control measures to ensure that a packet of seeds contained the varieties on the label; that the seeds would germinate and were clean of infection; and that there were no adulterants, weight-increasing stones, or weed seeds in the packet. However, the Act did not provide protection for the seed breeders and re-sowing of farm- or garden-saved seeds was not limited. Control over replanting saved seeds was first achieved in the 1930s through hybridisation.

Hybridisation, initially of maize in the USA, produced new plants with "hybrid vigour" and increased yields in the first generation. But this yield-enhancing technology also provided a quick solution to preventing re-sowing of farm-saved seeds as the second generation of seeds from hybridised varieties performed poorly. Farmers were forced to buy new seeds each year. While the availability of hybrid varieties has increased, not all crops are easy to hybridise and other measures were necessary to protect business interests. 
Table 1: World's Top Ten Seed Corporations

\begin{tabular}{lll}
\hline \multicolumn{2}{c}{ Company } & 2002 Seed sales (US\$ millions) \\
\hline 1 & Dupont (Pioneer) (USA) & 2,000 \\
2 & Monsanto (USA) & 1,600 \\
3 & Syngenta (Switzerland) & 937 \\
4 & Seminis (USA) & 453 \\
5 & Advanta (Netherlands) & 435 \\
6 & Groupe Limagrain (Vilmorin Clause, France) & 433 \\
7 & KWS AG (Germany) & 391 \\
8 & Sakata (Japan) & 376 \\
9 & Delta \& Pine Land (USA) & 258 \\
10 & Bayer Crop Science (Germany) & 250 \\
\hline
\end{tabular}

Source: ETC Group.

In the 1960s, the new Seeds Acts included provisions 'for the registration or licensing of persons engaged in the seeds industry or related activities'; and 'for ensuring that seeds on any official list remain true to variety' (The UK Plant Varieties and Seeds Act 1964) (Rangnekar 2000). This Act was developed in parallel with international legislation conferring greater rights to plant breeders, through the International Convention for the Protection of New Varieties of Plants (UPOV - International Convention for the Protection of New Varieties of Plants - 1961, 1972, 1978, 1991) and restrictions on seeds that could be traded to those on the "official list", especially as legislated by the European Union since 1964. The 1980s development of public sector high-response varieties of wheat, maize and rice for the "green revolution" popularised Modern Varieties, which increasingly were subject to plant breeders' rights.

While limited "plant patents" had been permitted in the USA for some decades, the 1980 landmark "Chakrabarty" ruling that a living micro-organism could be patented and the 1985 "Hibberd" corn (maize) patent, paved the way for life patents especially of genes and genomes that are increasingly incorporated in genetically modified (GM) varieties of crops and livestock (Kevles 2001).

When the Uruguay Round of negotiating a revision of the General Agreement on Tariffs and Trade (GATT) started in 1986, it was decided to include intellectual property protection and, as part of this, the protection of life patents. Though highly contested by many countries, this was included in the rules of the new WTO in 1985 . However, a concession was made that provided for a review of this provision after four years, i.e. in 1999. So far, this has not been completed: the terms of the review are still under discussion (Tansey 2002).

$\mathrm{FAO}$, as part of its obligations resulting from the 1992 United Nations Conference on Environment and Development, renegotiated the International Undertaking on plant genetic resources, in harmony with the Convention on Biological Diversity. This resulted in the International Seed Treaty (International Treaty on Plant Genetic Resources for Food and Agriculture - IT PGRFA) that became international law in 2004. This includes a clause that prohibits the claiming of intellectual property rights on any crops covered by the Treaty, although there is a disputed sub-clause "in the form received" that some interpret as licence to privatise any derivatives of the Treaty's crop varieties. ${ }^{2}$ The Treaty also codifies Farmers Rights, a move that has had mixed reactions as this limits previously "inalienable" but informal rights to freely exchange, save and sell seeds. The Treaty subordinates these rights to other national laws, which may include recognition of intellectual property rights on plant varieties and genes and hence restrict access and use.

One impact of plant breeders rights and exclusive contracts let to farmers by individual companies has been to criminalise farmers whose land has become contaminated with patented genes, for example from a genetically engineered (GE) variety. The Schmeiser case in Canada eventually found, on a split decision in the Supreme Court, in favour 
of Monsanto, which claimed theft of its intellectual property contained in a GE variety of canola (oil seed rape) but the Court did not demand that a technology fee should be paid. However, the farmer, Percy Schmeiser, was the victim of contamination and had unknowingly been replanting seeds containing Monsanto's patented genes. ${ }^{3}$ Many other similar cases are before the courts in North America.

The concern of farmers in the USA and Canada has spread to others whose crops are becoming contaminated by GE maize. For example, much of the maize in Mexico is now contaminated and farmers fear they will be subject to claims for technology fees from the owners of the patented genes that are in their crops (Mellen 2003). Food aid containing GE varieties is being sent by the USA to many countries, especially in Africa, causing similar concerns (Mulvany 2004).

At each stage of development - hybridisation, high-response (green revolution) varieties, genetic modification - the plant-breeding industry has used similar arguments that such varieties are essential to "feed the world", while, in effect, promoting the concentration of the industry by limiting access. The negative impact of concentration facilitated by patents on poverty reduction was recognised by the UK's Commission on Intellectual Property Rights (CIPR 2002).

The intention to limit access through plant breeders rights legislation has, though, had limited success and the majority of farm and garden seeds are still re-sown from year to year, and livestock breeding is predominately informal, outside of the industrial sector.

The solution for the plant-breeding industry has been to develop technology protection systems for plants the so-called Genetic Use Restriction Technologies (GURTs), dubbed Terminator and Traitor Technologies. These are designed to limit plant performance and include modifications that, for example, switch off the ability for seeds produced on-farm to germinate, hence forcing farmers to buy new seeds each season. There is a de facto moratorium, agreed by the $\mathrm{CBD}$, on the commercial exploitation of GURTs, supported by many African countries (CBD 2004). For example, at successive Conferences of the Parties of CBD, Kenya has presented strong opposition to GURTs, calling for an immediate ban on the development of these technologies. But many believe that the moratorium will collapse once the technology is perfected, given the continued pressure to adopt the technology, now presented somewhat disingenuously as a 'biosafety technology' (Le Page 2005).

This concentration of ownership of and control over plant genetic resources has been accelerating. In the 1900s, most seeds and livestock breeds were freely available to farmers and livestock breeders fostering local adaptation, conservation and development of agricultural biodiversity and supporting diverse food production systems. Now, most seeds sold are controlled by few corporations (Table 1).

According to the ETC Group, the top ten seed corporations accounted for combined seed revenues of over US\$7,000m in 2002 , or almost one-third (31 per cent) of the world's commercial seed sales, valued at approximately US $\$ 23,000 \mathrm{~m}$. But the global picture obscures a much stronger market concentration in specific segments. For example, four companies control over three-quarters of the world's commercial maize seed market, excluding China. Seven companies control $86 \%$ of commercial maize germplasm worldwide (ETC Group 2003).

With the ever-increasing spread of genetically modified crops containing patented genes, this concentration is also increasing. DuPont, Monsanto, Syngenta, Bayer and Dow currently derive sales from the biotechnology market worth approximately US $\$ 3,000 \mathrm{~m}$ in 2001 , according to Phillips McDougall AgriService (ETC Group 2003). The same companies that control germplasm are the ones developing GURTs and now investing in nano-biotechnologies that will enable manipulation and patentable control over not just the genes but also the atoms they are made of.

The development, testing and commercialisation of GM crops is strongly resisted by many farmers organisations in Africa. For example, the Kenya Small Scale Farmers Forum has organised a strong lobby against the promotion of GM crops by the Kenyan government, the Kenyan Agricultural Research Institute and international agricultural research associations, foundations and institutes based in Kenya. They issued the 'Thika Declaration' (2004) which says, among other things, 'GMOs will hand control of our food systems to the multinational companies, who have created these seeds for financial gain, and not for our need'.

Resistance to this control is increasing through the spread of seed fairs throughout the world, where farmers freely exchange seeds and knowledge. In 
Africa, farmers may exhibit more than 40 different varieties that they have grown in their own farms and gardens (see, e.g. Kisiangani 1999).

The World Forum on Food Sovereignty (WFFS 2001: 6), concluded:

Genetic resources are the result of millennia of evolution and belong to all of humanity. Therefore, there should be a prohibition on biopiracy and patents on living organisms, including the development of sterile varieties through genetic engineering processes. Seeds are the patrimony of all of humanity. The monopolisation by a number of transnational corporations of the technologies to create genetically modified organisms (GMOs) represents a grave threat to the peoples' food sovereignty. At the same time, in light of the fact that the effects of GMOs on health and the environment are unknown, we demand a ban on open experimentation, production and marketing until there is conclusive knowledge of their nature and impact, strictly applying the principle of precaution.

Actions to limit corporate control, such as the

\section{Notes}

1. See also resources and references at www.ukabc.org

2. IT PGRFA Article 12.3(d) states 'Recipients shall not claim any intellectual property or other rights that limit the facilitated access to the plant genetic resources for food and agriculture, or their genetic parts or components, in the form received from the Multilateral System'.

3. See www.percyschmeiser.com

\section{References}

Commission for Africa, 2005, Our Common Interest, London: Commission for Africa, www.commission forafrica.org/english/report/introduction.html (accessed April 2005)

CBD (Convention on Biological Diversity), 2004 , 'Advice on the report of the ad hoc technical expert group on the genetic use restriction technologies', Note by the Executive Secretary of the Subsidiary Body on Scientific, Technical and Technological Advance, 10th Meeting, Bangkok, 7-11 February, Report UNEP/CBD/ SBSTTA/10/15, www.biodiv.org/doc/meetings/ sbstta/sbstta-10/official/sbstta-10-15-en.pdf

CIPR (United Kingdom Commission on Intellectual Property Rights), 2002, 'Integrating Intellectual implementation of the African Model Law on community rights and the widespread adoption of farmers' seed fairs, are needed now to stem the haemorrhage of agricultural biodiversity and ensure the integrity of and continued open access to a wide diversity of genetic resources for food and agriculture in order to ensure food sovereignty and food security.

As Tewolde Egziabher (2002), the chief negotiator for the African Union on biodiversity and biosafety issues has said:

The aim of the Model $\mathrm{Law}^{4}$ is to protect the African local community from predation of its biodiversity, technology and knowledge, and to foster its development towards an appropriate industrialization that does not only have economic growth, but also the steady improvement of the wellbeing of every African as its dictate.

4. See African Model Legislation for the Protection of the Rights of Local Communities, Farmers and Breeders, and for the Regulation of Access to Biological Resources, www.grain.org/ $\mathrm{brl} /$ ? $\mathrm{docid}=798$ \&lawid $=2132$

Property Rights and Development Policy', Final report, London, September, www.iprcommis sion.org (accessed 27 February 2005)

Egziabher, T., 2002, The African Model Law for the Protection of the Rights of Local Communities, Farmers and Breeders, and for the Regulation of Access to Biological Resource in Relation to International Law and Institutions, www.biowatch.org.za/afmodlaw.htm (accesssed 27 February 2005)

ETC Group, 2003, Oligopoly, Inc. Concentration in Corporate Power, Ottawa: ETC Group, www.etcgroup.org/documents/Comm82Oligop NovDec03.pdf (accessed April 2005)

FAO, 1999, Sustaining Agricultural Biodiversity and Agro-Ecosystem Functions, Rome: Food and 
Agriculture Organization, www.fao.org/sd/ EPdirect/EPre0080.htm (accessed April 2005)

Kenya Small Scale Farmers Forum, 2004, 'The Thika Declaration on GMOs', www.grain.org/research/ contamination.cfm?id=161 (accessed 27 February 2005)

Kevles, D.J., 2001, Patenting Life: A Historical Overview of Law, Interests, and Ethics, New Haven, CT: Department of History, Yale University, www.yale.edu/law/ltw/papers/ltw-kevles.pdf (accessed April 2005)

Kisiangani, E., 1999, The Maragwa Seed Show, Nairobi: Intermediate Technology Development Group - Kenya, www.ukabc.org/maragwa.htm (accessed April 2005)

Le Page, M., 2005, “"Terminator” technology keeps GM crops in check', New Scientist, 28 February, www.newscientist.com/channel/life/gm-food/ mg18524886.100 (accessed April 2005)

Mellen, M., 2003, 'Interview with David Quist', Seedling, GRAIN, April, www.grain.org/seedling/ ?id=232 (accessed April 2005)

Mulvany, P., 2004, 'The dumping-ground: Africa and GM food aid', Open Democracy, www.organic consumers.org/biod/africa050404.cfm (accessed 27 February 2005)
Mulvany, P., 1999, 'TRIPs, biodiversity and commonwealth countries: capacity building priorities for the 999 review of TRIPs Article 27.3(b)', www.ukabc.org/TRIPs/cs_exsum.htm (accessed 27 February 2005)

Rangnekar, D., 2000, 'Intellectual property rights and agriculture: an analysis of the economic impact of plant breeders' rights', paper prepared for ActionAid, London: ActionAid, www.actionaid.org.uk/wps/content/documents/ ipr.pdf (accessed April 2005)

Tansey, G., 2002, 'Food security, biotechnology and intellectual property: unpacking some issues around TRIPs', Quaker United Nations Office, Geneva, July, www.qiap.ca/documents/FScol5.pdf (accessed 27 February 2005)

UKFG, 2003, Food Inc: Corporate Concentration from Farm to Consumer, London: United Kingdom Food Group, www.ukfg.org.uk/docs/UKFGFoodinc-Nov03.pdf (accessed April 2005)

WFFS, 2001, 'For the peoples' right to produce, feed themselves and exercise their food sovereignty', Final Declaration, Havana: World Forum on Food Sovereignty: 7 September, www.fao.org/tc/NGO/region/Havana_en.htm (accessed April 2005) 